\title{
Agriculture and Non-Agriculture Growth, Inflation and Income Inequality in Developed and Developing Countries
}

\author{
Sima Siami-Namini ${ }^{1}$ \\ ${ }^{1}$ Texas Tech University, Texas, USA \\ Correspondence: Sima Siami-Namini, Ph.D. Candidate, Texas Tech University, Texas, USA. E-mail: \\ Sima.Siami-Namini@ttu.edu
}

Received: September 7, 2019

Accepted: October 10, $2019 \quad$ Online Published: October 20, 2019

doi:10.5539/ijef.v11n11p43

URL: https://doi.org/10.5539/ijef.v11n11p43

\begin{abstract}
The aim of this article is to examine how agriculture and non-agriculture growth and inflation affect income inequality. The multivariate panel data approach is used to examine the application of Kuznets hypothesis between income inequality and agriculture and non-agriculture growth and test the existence of nonlinear relationship between income inequality and inflation rate in a large sample of data collected for developed and developing countries. The Hodrick-Prescott (HP) filter is used to separate the cyclical component from the trend component of inflation rate and agriculture and non-agriculture growth. The results demonstrate a significant negative nonlinear relationship between income inequality and the HP filtered inflation rate squared in developed countries. The findings confirm the application of a 'U-shaped' of Kuznets curve between income inequality and agriculture growth and between income inequality and non-agriculture growth in developed countries. In addition, the results show Kuznets inverted 'U-shaped' curve between agriculture growth and income inequality, and Kuznets 'U-shaped' curve between non-agriculture growth and income inequality in developing countries.
\end{abstract}

Keywords: inflation, income inequality, agriculture and non-agriculture growth, multivariate panel data approach

\section{Introduction}

In the mainstream literature, the study of the relationship between the economic growth, inflation, and the distribution of income is very important and has been devoted considerable attention of research from both academia and organizations. The equitable distribution of income with sustainable economic growth lies at the heart of an enduring issue in political economy and thus concerning some politicians and decision makers. Wright (2017) analyzed the relationship between the public's level of concern for income inequality and support for government intervention by using survey data going back to 1966 and found that support for government intervention do not follow the concern for income inequality (Figure 1). It is believed that the governments are responsible for inefficient fiscal policies that led to higher income inequality and inefficient allocation of resources. Furthermore, the gap between the poor and the rich people has accelerated by implementing an inefficient monetary policy in the countries.

In the economics of well-being, it is very important to increase economic welfare with avoiding income inequality which needs to increase economic growth and control surges in inflation or deflation. Kuznets (1955) analyzed the development path of the rich and the poor countries and developed the hypothesis that as an economy develops, income inequality first increases and then it decreases. He investigated the factors such as education, lower inter-sectoral productivity differences, lower return to capital, and political pressure for social transfers. He then looked at factors such as transfers of labor from agriculture to the other sectors specifically manufacturing and found that income inequality rises and reaches to its highest level and then decreases.

Historical data show that the gap between the rich and the poor is widening in all countries, specifically in the advanced countries, and therefore the current upswing in income inequality as the second Kuznets curve in the new age might be driven by the factors such as technological revolution and the transfer of the labor from more homogenous manufacturing into skilled heterogeneous services (Milanovic, 2016). 


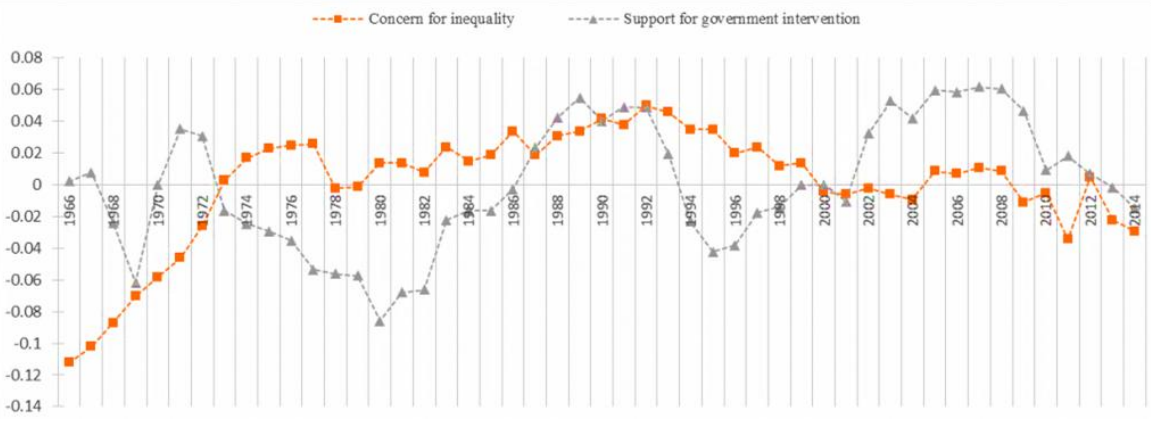

Figure 1. Concern for inequlity vs. support for government intervention

Source of Data: Wright (2017).

This article is a contribution to identifying the relationship between income inequality and agriculture and non-agriculture value added per capita on one hand, and the relationship between income inequality and inflation on the other hand. The study carried out for data over the 1990-2014 periods in a large sample of developed and developing countries. The author aims to quantify the underlie factors contributing to income inequality in the agriculture and non-agriculture sectors and determine any evidence for the existence of an inverted 'U-Shaped' Kuznets hypothesis between sectors growth and income inequality. The motivation behind of this article is to identify whether income inequality exists in developed and developing countries at their own stage of development. Addressing this question will help us draw practical inference for strategy policy considerations. In addition, this article determines if there is any nonlinear relationship between inflation and income inequality.

The rest of the article is organized as follows. Section 2 reviews the literature. Section 3 describes the data used for the study. Section 4 presents the methods of analysis. The results of regression analysis presented in Section 5, and Section 6 concludes the article.

\section{Literature Review}

There are a few studies on the factor influencing income inequality trying to understand why income inequality has increased in most countries. Some of these studies focus on the monetary policy's effects on income inequality while others analyze the fiscal policy effect. Some of the studies have considered the demographic factors and the others have investigated the effects of globalization and Foreign Direct Investment (FDI) on income inequality. This section reviews some of the related studies.

Adams (2003) investigated the impact of economic growth on poverty and inequality by using a panel data of 50 developing countries. He used two different approaches for economic growth including 1) measures by survey mean income (consumption), and 2) measures by Gross Domestic Product (GDP) per capita. The results showed a strong statistical relationship between the survey mean income or consumption and poverty reduction; whereas, no strong relationship between GDP per capita and poverty reduction was observed. Furthermore, Adams reported that the elasticity of poverty with respect to the survey mean income as a measure for economic growth accounted about -2.59 .

Liu and Sicular (2008) identified the determinants of nonagricultural income and employment and assessed the contribution of these determinants to income inequality in the Chinese economy. The results indicated that education inequality and regional development plays important roles in nonagricultural income inequality. According to their results, education inequality accounts for $9 \%$ and $36 \%$ of the wage and self-employment income inequality, while the community characteristics accounts for $46 \%$ and $32 \%$ of the wage and self-employment income inequality.

El Benni et al. (2011) discussed the development of income inequality in the production of Swiss agriculture by valley, hill and mountain regions for the period of 1990 to 2009. The results demonstrated that household income inequality increased in the sample of study. It was reported that the effects of agricultural policy reforms on income inequality were different in the regions. They found that: 1) an increase in direct payment income would decrease the household income inequality, and 2) off-farm income decreases income inequality; while 3) market income increases income inequality.

Khattak et al. (2014) examined the relationship between economic growth, income distribution, and inflation, and examined the existence of Kuznets hypothesis in Pakistan for the period of 1980-2002. They used Johnson's 
cointegration analysis and found that income inequality has a positive long-run relationship with economic growth, and inflation. The results confirmed the existence of Kuznets hypothesis in Pakistan. Ali et al. (2014) examined the effects of agriculture and service sector value added, exports and Foreign Direct Investment (FDI) on income inequality in Pakistan. The results showed that all variables, except service sector value added, have negative significant long-run effect on income inequality.

Bouincha and Karim (2018) analyzed the causality relationship between economic growth and inequality by using a panel data of 189 countries for the period of 1990-2015. The results showed that economic growth is not significant in the global model and in the developing countries, but it has statistically negative relationship with inequality in developed countries. The results confirmed the application of Kuznets hypothesis when economic growth is measured by the Human Development Indicator (HDI).

Siami-Namini and Hudson (2019a) investigated linear and nonlinear impacts of inflation on income inequality and tested the Kuznets hypothesis by using a panel data of 24 developed countries and 66 developing countries for the period of 1990 to 2014. They used the Toda- Yamamoto (1995) and Vector Error Correction Model (VECM) and found a nonlinear relationship between inflation and income inequality. They also confirmed the existence of Kuznets 'U-shaped' and inverted 'U-shaped' hypothesis between income inequality and real GDP per capita in developed and developing countries. They did not find bidirectional Granger causality between inflation and income inequality in the short-run, but there was in the long-run for both developed and developing countries.

Siami-Namini and Hudson (2019b) examined the effects of sector growth and monetary policy on income inequality by using a cross-country panel of 92 developing countries for the period 1990-2014. They found that agricultural and industrial sectors growth have a dominate impact in reducing income inequality. However, service sector growth had positive effect on income inequality in the developing countries. Their results confirmed the existence of Kuznets inverted 'U-shaped' hypothesis for industry sector growth and Kuznets 'U-shaped' hypothesis for service sector growth. They found that service sector growth and inflation affect income inequality in the long run.

Much of the studies and discussion regarding the relationship between economic growth and income inequality is based on Kuznets hypothesis. However, only a few studies have analyzed the nonlinear relationship between income inequality and inflation under the Kuznets hypothesis curve. Furthermore, there is no empirical evidence in analyzing the effects of agriculture and non-agriculture value added per capita, and inflation on income inequality and testing the application of Kuznets hypothesis in agriculture and non-agriculture value added per capita and at the same time examining the nonlinear relationship between inflation and income inequality is the main contribution of this article to the literature.

\section{Data}

The study and analyses carry out in this article are based on an annual balanced panel data set of 26 developed and 66 developing countries from 1990 to 2014, which have been collected from the World Bank website (Note 1). The author collected 1) the GINI index as a measure of income inequality, 2) real Gross Domestic Product (GDP) per capita (constant 2005 US\$), 3) Consumer Price Index (CPI) inflation, 4) urbanization index, 5) real agriculture and real non-agriculture value added per capita (constant 2005 US\$), 6) openness to international trade, and 7) unemployment rate.

The Hodrick and Prescott (1981) filter (the HP filter) is used to estimate the anticipated (long-run component) and unanticipated (short-run component) inflation, the HP filter absorbed real GDP and GDP gap (or the cyclical component of real GDP), and decomposes real agriculture and non-agriculture value added per capita by long-run and short-run components. Table 1 represents description of the data series.

Table 2 summarizes the descriptive statistics of the time series data collected for developed and developing countries. All the time series data are used in the log form. As reported in Table 2, for developed countries:

- The average of the log of real GDP per capita is 9.9223 ,

- The log of GINI index on average is 3.4573 (or 31.73 percent after taking antilog),

- The log of inflation rate on average is 1.1435 (or 3.138 percent after taking antilog),

- The log of real agriculture value added per capita on average is 6.0622 ,

- $\quad$ The $\log$ of real non-agriculture valued added per capita on average is 9.8944 . 
Table 1. Data description

\begin{tabular}{ll}
\hline Data & Description \\
\hline GINI & The GINI indexes \\
GDP & GDP per capita (constant 2005 US\$) \\
$\boldsymbol{\pi}$ & Inflation rate, consumer price index (annual percent) \\
$\boldsymbol{\pi}^{\text {hp }}$ & HP filtered inflation (long-run inflation trend) \\
$\boldsymbol{\pi}^{\text {gap }}$ & Inflation gap (short-run inflation or inflation cycles) \\
AGR & Agriculture, value added per capita (constant 2005 US\$) \\
AGR $^{\text {hp }}$ & HP filtered agriculture value added [long-run agriculture value added per capita trend (constant 2005 US\$)] \\
AGR $^{\text {gap }}$ & Agriculture value added gap (short-run agriculture value added per capita or agriculture value added per capita cycles) \\
NAGR & Non- agriculture value added per capita (constant 2005 US\$) \\
$\mathbf{N A G R}^{\text {hp }}$ & HP filtered non-agriculture value added [long-run non-agriculture value added per capita trend (constant 2005 US\$)] \\
$\mathbf{N A G R}^{\text {gap }}$ & Non-agriculture value added gap [short-run non-agriculture value added per capita or non-agriculture value added per \\
& capita cycles] \\
OPEN & Openness to international, trade (percent of GDP) \\
UR & Urbanization index, measured as a percentage of population living in urban areas \\
UN & Unemployment rate, total (percent of total labor force) (modeled ILO estimate) \\
\hline
\end{tabular}

On the other hand, for developing countries:

- The log of real GDP per capita on average is 7.1677,

- The log of GINI index on average is 3.7299 (or 41.67 percent after taking antilog),

- The log of inflation rate on average is 2.0347 (or 7.65 percent after taking antilog),

- The log of real agriculture value added per capita on average is 5.1566,

- The log of real non-agriculture valued added per capita on average is 6.9686.

Table 2. Descriptive statistics

\begin{tabular}{|c|c|c|c|c|c|c|c|c|c|c|}
\hline \multirow[b]{2}{*}{ Variables } & \multirow[b]{2}{*}{ Obs. } & \multirow[b]{2}{*}{ Mean } & \multirow[b]{2}{*}{$\operatorname{Max}$} & \multicolumn{3}{|c|}{ Developed Countries } & \multirow[b]{2}{*}{ Mean } & \multicolumn{2}{|c|}{ Developing Countries } & \multirow[b]{2}{*}{ Std. Dev. } \\
\hline & & & & Min & Std. Dev. & Obs. & & $\operatorname{Max}$ & Min & \\
\hline LGINI & 650 & 3.4573 & 4.1288 & 2.9699 & 0.1795 & 1650 & 3.7299 & 4.3457 & 2.7869 & 0.2341 \\
\hline LGDP & 650 & 9.9223 & 11.1432 & 7.5988 & 0.8805 & 1650 & 7.1677 & 9.3833 & 4.7351 & 1.0602 \\
\hline $\mathbf{L} \pi$ & 650 & 1.1435 & 7.3132 & -4.0739 & 1.2202 & 1650 & 2.0347 & 8.9202 & -3.3440 & 1.3576 \\
\hline $\mathbf{L} \pi^{\mathrm{hp}}$ & 650 & 1.1435 & 4.2542 & -0.4560 & 0.8143 & 1650 & 2.0347 & 5.7784 & -0.2630 & 0.9202 \\
\hline$L \pi^{\text {gap }}$ & 650 & $3.08 \mathrm{E}-12$ & 3.8340 & -4.7124 & 0.7931 & 1650 & $-3.03 \mathrm{E}-12$ & 5.4254 & -6.1352 & 0.8548 \\
\hline LAGR & 650 & 6.0622 & 7.1013 & 4.8219 & 0.5238 & 1650 & 5.1566 & 6.5694 & 3.5544 & 0.5502 \\
\hline LAGR $^{\text {hp }}$ & 650 & 6.0622 & 6.9288 & 4.9772 & 0.4768 & 1650 & 5.1566 & 6.5469 & 3.9287 & 0.5059 \\
\hline LAGR gap & 650 & $-2.00 \mathrm{E}-11$ & 0.9370 & -0.9447 & 0.1664 & 1650 & $-3.27 \mathrm{E}-11$ & 0.9794 & -0.9618 & 0.1665 \\
\hline LNAGR & 650 & 9.8944 & 11.1283 & 7.4946 & 0.8987 & 1650 & 6.9686 & 9.3503 & 3.9368 & 1.1944 \\
\hline LNAGR $^{\text {hp }}$ & 650 & 9.8945 & 11.1633 & 7.4845 & 0.8408 & 1650 & 6.9686 & 9.3689 & 4.1506 & 1.1149 \\
\hline LNAGR $^{\text {gap }}$ & 650 & $-4.62 \mathrm{E}-12$ & 1.1978 & -1.2488 & 0.2413 & 1650 & $2.06 \mathrm{E}-11$ & 1.8726 & -1.9051 & 0.3244 \\
\hline LOPEN & 650 & 4.3322 & 5.3125 & 2.9824 & 0.4743 & 1650 & 4.1751 & 5.3955 & 2.3748 & 0.5137 \\
\hline LUR & 650 & 4.2228 & 4.5831 & 3.0594 & 0.2758 & 1650 & 3.7218 & 4.5555 & 1.6894 & 0.5613 \\
\hline LUN & 650 & 2.0746 & 3.3069 & -0.5108 & 0.5352 & 1650 & 1.9285 & 3.6712 & -1.6094 & 0.8148 \\
\hline
\end{tabular}

\section{Method}

The author uses a multivariate panel data approach carried out in several steps as follows:

\subsection{The Relationship Amongst Income Inequality, Agricultural and Nonagricultural Growth}

As a general theory of income distribution, the author examines the application of the Kuznets hypothesis in the first step. Kuznets (1955) indicates that as per capita income increases, income inequality increases at first stage (developing or pre-industrial economies) but then, after reaching some turning point income inequality (industrial economies) starts declining (developed or post-industrial economies/service economy). Kuznets debates that the distribution of income becomes more unequal at the early stages of income growth but that the distribution eventually moves back toward greater equality as economic growth continues. This changing in 
relationship between per capita income and income inequality can be presented by a 'bell-shaped' curve or inverted 'U-shaped' known as the Kuznets hypothesis (Kuznets, 1955; 1963), which is in harmony with the Lewis dual economy model (Lewis, 1954).

According to the Kuznets's hypothesis of inverted 'U-shaped' in explaining the path of inequality, if agriculture workers all earn a low wage and industry workers earn an identical higher wage, then the transition from agriculture to industry will create an inverted ' $U$-shaped' in inequality. In time, as more of the population moves out of the traditional, rural, agriculture sector into the modern, urban, industry sectors and real wages in industry begin to rise, income inequality decreases (Deutsch and Silber, 2004).

The functional form of the model for investigating the contribution of economic sector growth in income inequality in this study is given by:

$$
\operatorname{lnGINI}_{i t}=\beta_{0}+\beta_{1}{\ln A G R_{i t}}+\beta_{2}\left(\ln A G R_{i t}\right)^{2}+\beta_{3} \ln N A G R_{i t}+\beta_{2} \ln N A G R_{i t}{ }^{2}+d \ln X_{i t}+\varepsilon_{i t}
$$

where:

- $\quad \operatorname{lnGINI}_{\mathrm{it}}$ is the log of GINI index as a measure of income inequality,

- $\ln A G R_{i t}$ is the log of real agriculture value added per capita,

- $\left(\ln \mathrm{AGR}_{\mathrm{it}}\right)^{2}$ is the log of real agriculture value added per capita squared,

- $\quad \operatorname{lnNAGR}_{\text {it }}$ is the log of real nonagricultural value added per capita,

- $\left(\operatorname{lnNAGR}_{\mathrm{it}}\right)^{2}$ is the log of real nonagricultural value added per capita squared,

- $\quad \ln X_{i t}$ is a set of control variables such as unemployment rate, urbanization, and openness to international trade,

- $\quad \varepsilon_{\text {it }}$ is the error term.

The subscript $i$ and $t$ denote country and time, respectively. The coefficient $\beta_{1}>0$ and $\beta_{2}<0$ and also $\beta_{3}>0$ and $\beta_{4}<0$ are regularly predicted in testing intended for the Kuznets inverted 'U-shaped' hypothesis for agricultural and nonagricultural sectors, respectively. The coefficient $\beta_{0}$ is the intercept term.

\subsection{The Nonlinear Relationship Between Income Inequality and Inflation}

Following the Amornthum (2004) and Bulir (2001), the author estimates the nonlinearity relationship between inflation and income inequality and test the application of the Kuznets hypothesis in the developed and developing countries. The effect of inflation and real agriculture and non-agriculture value added per capita on income inequality is distinguished between the long-run and the short-run. The general form of quadratic function is as

$$
\begin{aligned}
& \operatorname{lnGINI}_{i t}=\delta_{0}+\delta_{1}{\ln A G R_{i t}}+\delta_{2}\left(\ln A G R_{i t}\right)^{2}+\delta_{3} \ln N A G R_{i t}+\delta_{4}\left(\ln N A G R_{i t}\right)^{2}+ \\
& \delta_{5} \ln \pi_{i t}+\delta_{6}\left(\ln \pi_{i t}\right)^{2}+d \ln X_{i t}+\varepsilon_{i t}
\end{aligned}
$$

where:

- $\operatorname{GINI}_{\mathrm{it}}$ is the log of GINI index as a measure of income inequality,

- $\quad \ln A G R_{i t}$ is the log of real agricultural value added per capita,

- $\left(\ln A G R_{\mathrm{it}}\right)^{2}$ is the log of real agricultural value added per capita squared,

- $\quad \operatorname{lnNAGR}_{\text {it }}$ is the log of real nonagricultural value added per capita,

- $\quad\left(\operatorname{lnNAGR}_{\mathrm{it}}\right)^{2}$ is the log of real nonagricultural value added per capita squared,

- $\quad \ln \pi_{i t}$ is the log of inflation rate,

- $\left(\ln \pi_{\mathrm{it}}\right)^{2}$ is the $\log$ of inflation rate squared,

- $\quad \ln X_{\text {it }}$ is the $\log$ of control variables such as unemployment rate, urbanization, and openness to international trade,

- $\varepsilon_{\mathrm{it}}$ is the error term.

The subscript $i$ and $t$ denote country and time, respectively. The coefficient $\delta_{1}>0$ and $\delta_{2}<0$ and also $\delta_{3}>0$ and $\delta_{4}<0$ are regularly predicted in testing the application of Kuznets inverted 'U-shaped' hypothesis (Gallup, 2012). Also, the coefficient $\delta_{5}<0$ and $\delta_{6}>0$ are testing the application of nonlinearity relationship between inflation and income distribution. The coefficient $\beta_{0}$ is the intercept term. 


\section{Results}

This section evaluates the time series data for the purpose of stationary and non-stationary properties. The author applies panel data approach for testing the unit root null hypothesis. The power of the panel unit root test is higher than using a separate unit root test for each individual (country) time series (Levin et al., 2002). A panel data is denoted I (0) when it is stationary at each level, and I (d) when it must be different over the times in order to achieve stationarity. The results of panel unit root tests illustrate that some of time series data are stationary (integrated of order zero I (0) in level), and the other time series data are non-stationary (integrated of order one I (1) in level). In this article, the non-stationary variables become stationary after taking first difference. The empirical results of a multiple regression analysis fitted for the developed and developing countries' data are given in the two next subsections.

\subsection{The Estimation Results for Developed Countries}

The estimation results of the multivariate panel data regression analysis for the developed countries are presented in Table 3. The author estimated five individual models for the developed countries. As shown in Table 3, the results show a significant negative correlation between income inequality and the aggregated inflation rate in model (1) for the developed countries. Model (2) identifies a non-significant positive link between income inequality and the aggregated inflation rate, and a significant negative nonlinear link between income inequality and the aggregate inflation rate squared. In model (3), the results show a non-significant negative link between income inequality and the HP filtered inflation rate. In model (4), the results show a non-significant negative link between income inequality and the HP filtered inflation rate, and a non-significant negative relationship between income inequality and inflation gap or the cyclical component of inflation rate. In model (5), with the adding of the HP filtered inflation rate squared, the results show a significant positive linear relationship between income inequality and the HP filtered inflation rate, a significant negative nonlinear relationship between income inequality and the HP filtered inflation rate squared, and a non-significant negative link between income inequality and inflation gap in developed countries. As shown in Table 3, the $\mathrm{R}^{2}$ coefficient of determination are almost the same in all five estimated models for developed countries.

The author identifies a significant nonlinear link between real agriculture value added per capita and income inequality in all five models. However, the results are not consistent with the existence of an inverted 'U-shaped' of Kuznets curve between income inequality and real agriculture value added per capita. The results confirm the application of a 'U-shaped' of Kuznets curve between income inequality and the agriculture value added per capita for the developed countries. In all five estimated models, the coefficient of agriculture gap or the cyclical component of real agriculture value added per capita is positive, but it is not significant at 5 percent significance level. The same results are found for real non-agriculture value added per capita in all five models, which confirms the existence of a 'U-shaped' curve between non-agriculture value added per capita and income inequality. The coefficient of non-agriculture gap or the cyclical component of real non-agriculture value added per capita is a positive correlation statistically significant at 5 percent significance level in model (1), (3), and (4). The results show a significant positive pro-cyclical link between non-agriculture gap and income inequality in all five estimated models in developed countries.

The other control variables are significant at 5 percent significance level in all five models. The findings show a significant positive relationship between unemployment rate and income inequality as expected. The results show a significant negative link between openness to trade and income inequality, and a significant negative relationship between urbanization index and income inequality in all five models for developed countries (Siami-Namini \& Hudson, 2019a and 2019b; Siami-Namini, 2019; Shirvani et al., 2019; Shirvani \& Volchenkov, 2019; Siami-Namini et al., 2018; Siami-Namini, 2017; Khalessi \& Siami-Namini, 2004).

\subsection{The Estimation Results for Developing Countries}

The estimation results of the multivariate panel data regression analysis for the developing countries are presented in Table 3. The author estimated five separate models simultaneously for the developing countries. As shown in Table 3, the results show a significant negative correlation between income inequality and the aggregate inflation rate in model (1). In model (2), the author identifies a non-significant negative link between income inequality and the aggregate inflation rate and a significant negative link between income inequality and the aggregate inflation rate squared at 10 percent significance level. The results also show a negative significant link between income inequality and the HP filtered inflation rate in model (3). The results show a non-significant negative link between income inequality and inflation gap or the cyclical component of inflation rate in model (4). In model (5), with the adding of the HP filtered inflation squared for testing the existence of a nonlinear relationship, the findings show a significant negative linear relation between income inequality and the HP 
filtered inflation rate and also a non-significant positive relationship between income inequality and the HP filtered squared for the developing countries. The coefficient of inflation gap or the cyclical component of inflation rate is negative, but it is not significant. The $\mathrm{R}^{2}$ coefficients of determination are almost the same in all five estimated models in the developing countries.

The author observes a significant nonlinear link between real agriculture value added per capita and income inequality in all five models at 10 percent significant level. The results are consistent with the existence of Kuznets inverted 'U-shaped' hypothesis between income inequality and real agriculture value added per capita. That is, as real agriculture value added per capita increases, income inequality first goes up and then comes back down. Similar results were also observed for real non-agriculture value added per capita in all five models for the developing countries. However, for this case, the results are consistent with the existence of Kuznets 'U-shaped' hypothesis between income inequality and real non-agriculture value added per capita. The results show a significant negative link between agriculture gap or the cyclical component of real agriculture value added per capita and income inequality, and a significant positive relationship between non-agriculture gap or the cyclical component of real non-agriculture value added per capita and income inequality in all five estimated models in the developing countries.

Table 3. The results of the regression analysis

\begin{tabular}{|c|c|c|c|c|c|c|c|c|c|c|}
\hline \multirow{2}{*}{$\begin{array}{c}\text { Dependent } \\
\text { Variable: } \\
\text { LGINI }\end{array}$} & \multicolumn{5}{|c|}{ Developed Countries } & \multicolumn{5}{|c|}{ Developing Countries } \\
\hline & (1) & (2) & (3) & (4) & (5) & (1) & (2) & (3) & (4) & (5) \\
\hline $\mathrm{C}$ & $\begin{array}{l}14.3086 \\
(0.0000)\end{array}$ & $\begin{array}{l}14.1907 \\
(0.0000)\end{array}$ & $\begin{array}{l}14.3599 \\
(0.0000)\end{array}$ & $\begin{array}{l}14.2860 \\
(0.0000)\end{array}$ & $\begin{array}{l}15.0112 \\
(0.0000)\end{array}$ & $\begin{array}{c}3.7864 \\
(0.0000)\end{array}$ & $\begin{array}{c}3.8118 \\
(0.0000)\end{array}$ & $\begin{array}{c}3.7931 \\
(0.0000)\end{array}$ & $\begin{array}{c}3.7988 \\
(0.0000)\end{array}$ & $\begin{array}{c}3.7987 \\
(0.0000)\end{array}$ \\
\hline LAGR $^{\text {hp }}$ & $\begin{array}{l}-2.7497 \\
(0.0000)\end{array}$ & $\begin{array}{l}-2.5690 \\
(0.0000)\end{array}$ & $\begin{array}{l}-2.8228 \\
(0.0000)\end{array}$ & $\begin{array}{l}-2.7537 \\
(0.0000)\end{array}$ & $\begin{array}{l}-1.6236 \\
(0.0000)\end{array}$ & $\begin{array}{c}0.2098 \\
(0.0670)\end{array}$ & $\begin{array}{c}0.1866 \\
(0.0994)\end{array}$ & $\begin{array}{c}0.1995 \\
(0.0821)\end{array}$ & $\begin{array}{c}0.1950 \\
(0.0895)\end{array}$ & $\begin{array}{c}0.1959 \\
(0.0886)\end{array}$ \\
\hline$\left(\mathrm{LAGR}^{\mathrm{hp}}\right)^{2}$ & $\begin{array}{c}0.2241 \\
(0.0000)\end{array}$ & $\begin{array}{c}0.2087 \\
(0.0000)\end{array}$ & $\begin{array}{c}0.2302 \\
(0.0000)\end{array}$ & $\begin{array}{c}0.2244 \\
(0.0000)\end{array}$ & $\begin{array}{c}0.1321 \\
(0.0000)\end{array}$ & $\begin{array}{l}-0.0276 \\
(0.0114)\end{array}$ & $\begin{array}{l}-0.0254 \\
(0.0185)\end{array}$ & $\begin{array}{l}-0.0263 \\
(0.0154)\end{array}$ & $\begin{array}{l}-0.0260 \\
(0.0172)\end{array}$ & $\begin{array}{l}-0.0259 \\
(0.0174)\end{array}$ \\
\hline LAGR $^{\text {gap }}$ & $\begin{array}{c}0.0321 \\
(0.2916)\end{array}$ & $\begin{array}{c}0.0518 \\
(0.0714)\end{array}$ & $\begin{array}{c}0.0376 \\
(0.1931)\end{array}$ & $\begin{array}{c}0.0320 \\
(0.2925)\end{array}$ & $\begin{array}{c}0.0426 \\
(0.1187)\end{array}$ & $\begin{array}{l}-0.0598 \\
(0.0169)\end{array}$ & $\begin{array}{l}-0.0515 \\
(0.0398)\end{array}$ & $\begin{array}{l}-0.0810 \\
(0.0011)\end{array}$ & $\begin{array}{l}-0.0803 \\
(0.0014)\end{array}$ & $\begin{array}{l}-0.0780 \\
(0.0021)\end{array}$ \\
\hline LNAGR $^{\text {hp }}$ & $\begin{array}{l}-0.2050 \\
(0.1968)\end{array}$ & $\begin{array}{l}-0.3016 \\
(0.0519)\end{array}$ & $\begin{array}{l}-0.1876 \\
(0.2385)\end{array}$ & $\begin{array}{l}-0.1996 \\
(0.2140)\end{array}$ & $\begin{array}{l}-1.1489 \\
(0.0000)\end{array}$ & $\begin{array}{l}-0.0969 \\
(0.0307)\end{array}$ & $\begin{array}{l}-0.0861 \\
(0.0509)\end{array}$ & $\begin{array}{l}-0.0805 \\
(0.0770)\end{array}$ & $\begin{array}{l}-0.0786 \\
(0.0846)\end{array}$ & $\begin{array}{l}-0.0817 \\
(0.0716)\end{array}$ \\
\hline$\left(\mathrm{LNAGR}^{\mathrm{hp}}\right)^{2}$ & $\begin{array}{l}0.01527 \\
(0.0634)\end{array}$ & $\begin{array}{c}0.0193 \\
(0.0160)\end{array}$ & $\begin{array}{c}0.0146 \\
(0.0728)\end{array}$ & $\begin{array}{c}0.0151 \\
(0.0679)\end{array}$ & $\begin{array}{c}0.0634 \\
(0.0000)\end{array}$ & $\begin{array}{c}0.0148 \\
(0.0000)\end{array}$ & $\begin{array}{c}0.0140 \\
(0.0000)\end{array}$ & $\begin{array}{c}0.0135 \\
(0.0000)\end{array}$ & $\begin{array}{c}0.0134 \\
(0.0000)\end{array}$ & $\begin{array}{c}0.0135 \\
(0.0000)\end{array}$ \\
\hline LNAGR $^{\text {gap }}$ & $\begin{array}{c}0.0931 \\
(0.0006)\end{array}$ & $\begin{array}{c}0.0340 \\
(0.2307)\end{array}$ & $\begin{array}{c}0.1080 \\
(0.0000)\end{array}$ & $\begin{array}{c}0.0927 \\
(0.0007)\end{array}$ & $\begin{array}{c}0.0367 \\
(0.1584)\end{array}$ & $\begin{array}{c}0.0662 \\
(0.0000)\end{array}$ & $\begin{array}{c}0.0631 \\
(0.0000)\end{array}$ & $\begin{array}{c}0.0759 \\
(0.0000)\end{array}$ & $\begin{array}{c}0.0755 \\
(0.0000)\end{array}$ & $\begin{array}{c}0.0749 \\
(0.0000)\end{array}$ \\
\hline $\mathrm{L} \pi$ & $\begin{array}{l}-0.0088 \\
(0.0688)\end{array}$ & $\begin{array}{c}0.0058 \\
(0.2436)\end{array}$ & - & - & - & $\begin{array}{l}-0.0104 \\
(0.0000)\end{array}$ & $\begin{array}{l}-0.0040 \\
(0.3440)\end{array}$ & - & - & - \\
\hline$(L \pi)^{2}$ & - & $\begin{array}{l}-0.0064 \\
(0.0000)\end{array}$ & - & - & - & - & $\begin{array}{l}-0.0014 \\
(0.0982)\end{array}$ & - & - & - \\
\hline $\mathrm{L} \pi^{\mathrm{hp}}$ & - & - & $\begin{array}{l}-0.0019 \\
(0.8367)\end{array}$ & $\begin{array}{l}-0.0069 \\
(0.4701)\end{array}$ & $\begin{array}{c}0.1520 \\
(0.0000)\end{array}$ & - & - & $\begin{array}{l}-0.0274 \\
(0.0000)\end{array}$ & $\begin{array}{l}-0.0271 \\
(0.0000)\end{array}$ & $\begin{array}{l}-0.0272 \\
(0.0197)\end{array}$ \\
\hline$\left(\mathrm{L} \pi^{\mathrm{hp}}\right)^{2}$ & - & - & - & - & $\begin{array}{l}-0.0484 \\
(0.0000)\end{array}$ & - & - & - & - & $\begin{array}{c}0.0002 \\
(0.9311)\end{array}$ \\
\hline$L \pi^{g a p}$ & - & - & - & $\begin{array}{l}-0.0096 \\
(0.1027)\end{array}$ & $\begin{array}{l}-0.0081 \\
(0.1176)\end{array}$ & - & - & - & $\begin{array}{l}-0.0005 \\
(0.8787)\end{array}$ & $\begin{array}{l}-0.0074 \\
(0.8402)\end{array}$ \\
\hline LOPEN & $\begin{array}{l}-0.0936 \\
(0.0000)\end{array}$ & $\begin{array}{l}-0.0904 \\
(0.0000)\end{array}$ & $\begin{array}{l}-0.0865 \\
(0.0000)\end{array}$ & $\begin{array}{l}-0.0935 \\
(0.0000)\end{array}$ & $\begin{array}{l}-0.1028 \\
(0.0000)\end{array}$ & $\begin{array}{l}-0.0479 \\
(0.0000)\end{array}$ & $\begin{array}{l}-0.0489 \\
(0.0000)\end{array}$ & $\begin{array}{l}-0.0547 \\
(0.0000)\end{array}$ & $\begin{array}{l}-0.0547 \\
(0.0000)\end{array}$ & $\begin{array}{l}-0.0533 \\
(0.0000)\end{array}$ \\
\hline LUN & $\begin{array}{c}0.0661 \\
(0.0000)\end{array}$ & $\begin{array}{c}0.0589 \\
(0.0000)\end{array}$ & $\begin{array}{c}0.0700 \\
(0.0000)\end{array}$ & $\begin{array}{c}0.0665 \\
(0.0000)\end{array}$ & $\begin{array}{c}0.0642 \\
(0.0000)\end{array}$ & $\begin{array}{c}0.0283 \\
(0.0000)\end{array}$ & $\begin{array}{c}0.0283 \\
(0.0000)\end{array}$ & $\begin{array}{c}0.0310 \\
(0.0000)\end{array}$ & $\begin{array}{c}0.0310 \\
(0.0000)\end{array}$ & $\begin{array}{l}0.03100 \\
(0.0000)\end{array}$ \\
\hline LUR & $\begin{array}{l}-0.3936 \\
(0.0000)\end{array}$ & $\begin{array}{l}-0.3580 \\
(0.0000)\end{array}$ & $\begin{array}{l}-0.3926 \\
(0.0000)\end{array}$ & $\begin{array}{c}-0.3944 \\
(0.0000)\end{array}$ & $\begin{array}{c}-0.2938 \\
(0.0000)\end{array}$ & $\begin{array}{l}-0.0764 \\
(0.0000)\end{array}$ & $\begin{array}{l}-0.0765 \\
(0.0000)\end{array}$ & $\begin{array}{c}-0.0711 \\
(0.0000)\end{array}$ & $\begin{array}{l}-0.0715 \\
(0.0000)\end{array}$ & $\begin{array}{l}-0.07047 \\
(0.0000)\end{array}$ \\
\hline$R^{2}$ & 0.44 & 0.47 & 0.44 & 0.44 & 0.50 & 0.30 & 0.30 & 0.32 & 0.32 & 0.31 \\
\hline
\end{tabular}

Note. Probability values are in parenthesis.

The other control variables are significant at 5 percent significance level in all five estimation models. The results show a significant positive relationship between unemployment rate and income inequality. The results 
show a significant negative link between openness to trade and income inequality, and a significant negative relationship between urbanization index and income inequality in all five estimated models for the developing countries.

\section{Conclusion}

This article explores the relationship amongst real agriculture and non-agriculture value added per capita, inflation and income inequality in a large sample of data collected for selected developed and developing countries. The multivariate panel data approach is used to examine the application of Kuznets hypothesis between income inequality and agriculture and non-agriculture growth and test the existence of nonlinear relationship between income inequality and inflation rate. The panel unit root test is used to identify the stationary of time series data. The HP filter is used to separate the cyclical component from the trend component of inflation rate and real agriculture and non-agriculture value added per capita.

The author estimates five individual models for both developed and developing countries. The results describe a significant positive linear relationship between income inequality and the HP filtered inflation rate, a significant negative nonlinear relationship between income inequality and the HP filtered inflation rate squared, and a non-significant negative link between income inequality and inflation gap in the developed countries. For developing countries, the findings show a significant negative linear relation between income inequality and the HP filtered inflation rate, and a non-significant positive relationship between income inequality and the HP filtered squared.

The author uses real agriculture and non-agriculture value added per capita as two components of GDP. The results confirm the application of a 'U-shaped' of Kuznets curve between income inequality and agriculture value added per capita and between income inequality and non-agriculture value added per capita in developed countries. The results show the existence of nonlinear relation between real agriculture value added per capita and income inequality (inverted 'U-shaped' curve), and between non-agriculture value added per capita and income inequality ('U-shaped' curve) for developing countries.

The results show a significant positive relationship between unemployment rate and income inequality, a significant negative link between openness to trade and income inequality, and a significant negative relationship between urbanization index and income inequality in all estimation models for both developed and developing countries.

\section{References}

Adams, R. H. J. (2003). Economic growth, inequality, and poverty: Findings from a new data set (English). Policy. Research Working Paper No. WPS 2972. Washington, DC, World Bank.

Ali, S., Mustafa, M. Q., \& Shahbazi, I. A. (2013). Agriculture value added and income inequality in Pakistan: A time series analysis. Research Journal of Economics, Business and ICT, 8(2), 25-33.

Amornthum, S. (2004). Income inequality, inflation and nonlinearity: The case of Asian economies.

Bouincha, M., \& Karim, M. (2018). Income inequality and economic growth: An analysis using a panel data. International Journal of Economics and Finance, 10(5), 242-253. https://doi.org/10.5539/ijef.v10n5p242

Bulir, A. (2001). Income inequality: does inflation matter? IMF Staff Paper, 48(1). https://doi.org/10.5089/9781451928549.001

Deutsch, J., \& Silber, J. (2004). Measuring the impact of various income sources on the link between inequality and development: Implications for the Kuznets curve. Review of Development Economics, 8(1), 110-127. https://doi.org/10.1111/j.1467-9361.2004.00223.x

El Benni, N., \& Finger, R. (2011). The effect of agricultural policy reforms on income inequality in Swiss agriculture - An analysis for valley, hill and mountains regions. 2011 International Congress, Zurich, Switzerland, European Association of Agricultural Economists.

Gallup, J. L. (2012). Is there a Kuznets curve? Portland State University.

Hodrick, R., \& Prescott, E. (1981). Post-war U.S. business cycles: An empirical investigation. Journal of Money, Credit and Banking, 29(1), 1-16. https://doi.org/10.2307/2953682

Khalessi, A., \& Siami-Namini, S. (2004). Estimation of non-accelerating inflation rate of unemployment (NAIRU) and potential output. The Journal of Planning and Budgeting, 9(3), 67-94.

Khattak, D., Muhammad, A., \& Iqbal, K. (2014). Determining the relationship between income inequality, economic growth \& inflation. Journal of Social Economics, 1(3), 104-114. 
Kuznets, S. (1955). Economic growth and income inequality. The American Economic Review, 45(1), 1-28.

Kuznets, S. (1963). Quantitative aspects of the economic growth of nations: VIII, distribution of income by size. Economic Development and Cultural Change, 11(2), 1-80. https://doi.org/10.1086/450006

Levin, A., Lin, C. F., \& Chu, C. S. J. (2002). Unit root tests in panel data: Asymptotic and finite- sample properties. Journal of Econometrics, 108(1), 1-24. https://doi.org/10.1016/S0304-4076(01)00098-7

Lewis, W. A. (1954). Economic development with unlimited supplies of labor. Manchester School of Economic and Social Studies, 22(2), 139-91. https://doi.org/10.1111/j.1467-9957.1954.tb00021.x

Liu, X., \& Sicular, T. (2008). Non-agricultural employment determinants and income inequality decomposition. EPRI Working Papers, Economic Policy Research Institute, Western University.

Milanovic, B. (2016). Global inequality: A new approach for the age of globalization. Harvard University Press. https://doi.org/10.4159/9780674969797

Shirvani, A., \& Volchenkov, D. (2019). A regulated market under sanctions: on Tail dependence between oil, gold, and Tehran stock exchange index. Journal of Vibration Testing and System Dynamics, 3(3), 297-311. https://doi.org/10.5890/JVTSD.2019.09.004

Shirvania, A., Stoyanovb, S. V., Fabozzic, F. J., \& Rachev, S. T. (2019). Equity premium puzzle or faulty economic modelling? Retrieved from https://arxiv.org/abs/1909.13019v1

Siami-Namini, S. (2019). Volatility transmission among oil price, exchange rate and agricultural commodities prices. Applied Economics and Finance, 6(4), 41-61. https://doi.org/10.11114/aef.v6i4.4322

Siami-Namini, S., \& Hudson, D. (2019a). Inflation and income inequality in developed and developing countries. Journal of Economic Studies, 46(3), 611-632. https://doi.org/10.1108/JES-02-2018-0045

Siami-Namini, S., \& Hudson, D. (2019b). The impacts of sector growth and monetary policy on income inequality in developing countries. Journal of Economic Studies, 46(3), 591-610. https://doi.org/10.1108/JES-08-2017-0243

Siami-Namini, S., Tavakoli, N., \& Siami Namin, N. (2018). A comparison of ARIMA and LSTM in forecasting time series. 2018 17th IEEE International Conference on Machine Learning and Applications (ICMLA), Orlando, FL, 2018, pp. 1394-1401.

Siami-Namini, S. (2017). Granger causality between gross domestic product and economic sectors in developing countries: A panel cointegration approach. International Journal of Economics and Financial Issues, 7(5), 53-58.

Wright. (2017). Retrieved from https://qz.com/991448/inequality-is-a-concern-for-americans-but-they-dontthink-the-government-should-do -anything-about-it/

Note

Note 1. https://www.worldbank.org/

\section{Copyrights}

Copyright for this article is retained by the author(s), with first publication rights granted to the journal.

This is an open-access article distributed under the terms and conditions of the Creative Commons Attribution license (http://creativecommons.org/licenses/by/4.0/). 